\title{
Research Paper \\ Diazinon Residues in Rice and Associated Health Risks for Human; A Case Study in Rasht, Iran
}

\author{
Fatemeh Ghanbari $^{1 *}$ (D), Maryam Kiani Sadr ${ }^{2}$ (D), Masoud Kouckakian ${ }^{3}$ (D), Kobra Melhosseini Darani ${ }^{4}$ (D) \\ 1. Environmental Research Institute, Academic Center for Education, Culture and Research (ACECR), Rasht, Iran. \\ 2. Department of Environment, Faculty of Basic Sciences, Hamedan Branch, Islamic Azad University, Hamedan, Iran. \\ 3. Infrastructural \& the Environment of the Supreme Council of Iran's FTZS, Free-Trade Zone, Iran. \\ 4. Department of Environmental Sciences, Faculty of Natural Resources \& Environment, Malayer University, Malayer, Iran.
}

\begin{tabular}{|l|l|}
$\begin{array}{c}\text { Use your device to scan } \\
\text { and read the article online }\end{array}$ & $\begin{array}{l}\text { Cittation Ghanbari F, Kiani Sadr M, Kouckakian M, Melhosseini Darani K. Diazinon Residues in Rice and Associated Health } \\
\text { Risks for Human; A Case Study in Rasht, Iran. Journal of Advances in Environmental Health Research. 2021; 9(2):169-176. } \\
\text { http://dx.doi.org/10.32598/JAEHR.9.2.1211 }\end{array}$ \\
doi: $:$ http://dx.doi.org/10.32598/JAEHR.9.2.1211
\end{tabular}

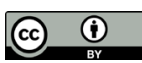

Article info:

Received: 05 Dec 2020

Accepted: $21 \mathrm{Feb} 2021$

Publish: 01 Apr 2021

\section{Keywords:}

Diazinon, Health risk index, Reference dose, Pesticide residue, Cereals

\section{ABSTRACT}

Background: Rice is the most important agricultural crop and the main food in Gilan and Mazandaran Provinces in northern Iran where organophosphorus pesticides, especially diazinon, are used. The excessive use of this insecticide in the paddy fields of Rasht County is a serious threat to people's health.

Methods: In this study, 30 rice samples were collected from five zones in the paddy fields of Rasht in summer. The samples were analyzed when rice is sold to assess the health risk caused by diazinon residues in rice. Following the digestion process, the samples were injected into a HighPerformance Liquid Chromatography (HPLC) instrument. Analysis of Variance (ANOVA) and one-sample t-test were respectively used for analyzing data and the Health Risk Index (HRI) for assessing the risk of rice consumption.

Results: According to the results, the mean residual diazinon concentration in the rice crops of the five studied zones at the time of consumption (three months after harvest) was $0.4 \pm 0.43 \mathrm{mg}$ / $\mathrm{kg}^{-1}$. This was higher than the Iranian standard for permissible diazinon concentration in rice. The results of the health risk assessment for rice consumption indicated an HRI value of 0.13 for rice consumption, which did not constitute a serious risk for people who consume rice regularly.

Conclusion: Although the results of this study showed that there are no potential health risks for consumers, with increasing the use of chemical pesticides for crops, to achieve food safety, regular monitoring of pesticide residues in crops is recommended.

\section{Introduction}

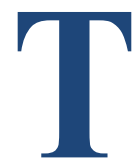

he increasing global need for food due to the growing population is of particular importance. Consequently, pests of agricultural crops are considered a major dilemma despite the unavoidable use of pesticides for improving the yield of crops $[1,2]$. Pesticides consist of a vast abundance of chemicals that are used to prevent, defeat, and decrease pests in different stages of crop cultivation [3]. Pesti-

\footnotetext{
* Corresponding Author:

Fatemeh Ghanbari, PhD.

Address: Environmental Research Institute, Academic Center for Education, Culture and Research (ACECR), Rasht, Iran.

Phone: +98 (911) 3372839

E-mail:ft.ghanbari@gmail.com
} 
cides are chemicals that control insects, fungi, weeds, and other pests damaging crops [4-6]. According to the Food and Agriculture Organization (FAO), about 3.8 million tons of pesticides were used in agricultural lands in 2012 [7]. Biological problems resulting from pesticide application include the destruction of beneficial insects and natural enemies of pests, the emergence of pesticideresident pests, and the reduction of biodiversity. More than two million people, mostly in developing countries, are also exposed to health problems resulting from the application of pesticides [8]. The pesticide residues in food products have an adverse effect on human health [9]. Despite the benefits of pesticides for improving the yield of crops, their extensive use can increase the contamination of soil and surface waters causing serious environmental and health hazards [10, 11]. The standard models introduced by accredited international organizations are used to cope with the increased probability of developing cancers and non-cancer diseases caused by pesticides. Indices mainly based on the concentration of applied pesticides, including Hazard Quotient (HQ) and Hazard Index (HI), are used to assess the health risks of pesticides $[12,13]$. The use of Organochlorine Pesticides (OCPs) has been banned in many countries due to their environmental persistence and accumulation in the food chain ad also their undesirable effects on humans. This has led to the increased use of other pesticides, such as Organophosphate Pesticides (OPPs) that are less persistent than OCPs $[14,15]$. However, these pesticides are among the hazardous chemicals [16] because of their residues in agricultural products [17].

Striped rice stem borer (Chilo suppressalis) is one of the most destructive rice pests found all over the world. It affects rice plants at their various growth stages and causes dead hearts or dying of the central tiller during the vegetative stage and empty and whitish looking panicles (whiteheads). A common method for controlling this pest is to use effective pesticides with fewer side effects [18-20]. According to the data from the Gilan Organization of Agriculture, Rasht has the largest area under rice cultivation in Gilan Province and Chilo suppressalis is the most important pest found in rice paddies. Consequently, the OPP diazinon (in its liquid and granulated forms) is commonly applied to rice paddies to control this pest. In addition to contaminating soil and water resources, diazinon may accumulate in rice posing a serious threat to the health of rice consumers. Therefore, it is very important to detect diazinon in rice produced in the paddies of Gilan Province. This study was done to determine the safety of rice produced in Rasht in terms of diazinon residues.

\section{Materials and Methods}

\section{Sampling}

The study area (Figure 1), the eastern part of the Anzali Wetland, consists of five zones with a total area of 81478.71 ha. Based on the 2011 Census, Rasht has a population of more than 900000 people.

Sampling was carried out according to the international method recommended by the Codex Committee (Codex Alimentarius 2000.01.24). In this method, each sampling region or district based on geographical conditions is divided into the northern, southern, eastern, western, and southern zones, each of which is sub-divided into six sections or plots of agricultural lands. Three rice samples were taken from each plot and mixed to form working samples, which were transferred to the laboratory (European Commission, 2003). Figure 1 presents the five selected zones. Furthermore, based on the basic research, in which low-persistence OPPs with short halflives were studied, backups were prepared for all the samples collected at harvest in the summer and kept at room temperature. These backups were analyzed almost three months later at the time of selling the rice crop in the market.

\section{Sample extraction}

The rice grains were first dried at ambient temperature and then, their husks were removed. Each sample had its grains ground separately to determine its diazinon residue. Using Soxhlet extraction, $5 \mathrm{~g}$ of each ground sample was wetted by water and after $2 \mathrm{~h}$, was put in the ultrasonic instrument for $4 \mathrm{~min}$ to be ready for extraction. The sample was then transferred into the $50-\mathrm{mL}$ Soxhlet extractor and the extraction process was completed in 4 $\mathrm{h}$ using petroleum ether. Diazinon was determined using the gas chromatographic method. Three microliters of the extract were injected into a gas chromatograph (Shimadzu-9A) using the following parameters and operating conditions: flame ionization detector and capillary GC column $30 \mathrm{~m} \times 0.53 \mathrm{~mm}$ packed with a mixture of $200+2.0 \% \mathrm{OV}-17$ and $4.5 \% \mathrm{DC}$, chromosorb WAW; column temperature: $240{ }^{\circ} \mathrm{C}$ and detector temperature: $275^{\circ} \mathrm{C}$. Peak areas and retention times were calculated by comparison of retention time obtained from standard solutions of comparable strength [21]. The solvent was then evaporated and the dried compound was dissolved in $0.5 \mathrm{~mL}$ methanol, and $20 \mu \mathrm{L}$ of the prepared solution was injected into the HPLC instrument. HPLC was equipped with a diode array detector and an SGE C18 RS column $(250 \times 4.6 \mathrm{~mm}, 5 \mu \mathrm{m})$ [22]. For each sample, the injection process was repeated three times, and 
qualitative and quantitative measurements were done after comparison with the standard spectra, and the recorded data were reported. The mobile phase for the rice samples contained $80 \%$ methanol, 15\% double-distilled water, and $5 \%$ acetonitrile.

\section{Statistical analysis}

The data were analyzed using Microsoft Excel and SPSS 16. After confirming data normality, the concentration and dispersion criteria, such as mean, variance, standard deviation, standard error, and bar graphs were used in the descriptive analysis. The one-sample t-test and one-way Analysis of Variance (ANOVA) were employed in the analytic section. Parametric one-way ANOVA was then used for the normal data to compare the zones with respect to diazinon residues in rice grains.

\section{Heath risk assessment}

\section{Calculating Health Risk Index (HRI)}

The equation for HRI was used to determine the risk resulting from diazinon application for the rice samples in the studied area. The HRI has been recommended by the United States Environmental Protection Agency (US EPA) and is used in many references to identify the health risk [16, 23-25].

$$
\begin{aligned}
& \mathrm{HRI}=\frac{\mathrm{EADI}}{\mathrm{ADI}} \\
& \mathrm{EADI}=\frac{\mathrm{RPC} \times \mathrm{FCR}}{\mathrm{BW}}
\end{aligned}
$$

Where, EADI, RPC, FCR, and ADI are the estimated average daily intake, the residual pesticide concentration $\left(\mathrm{mg} / \mathrm{day}^{-1}\right)$, the food consumption rate $\left(\mathrm{kg} / \mathrm{day}^{-1}\right)$, and the acceptable daily intake $\left(\mathrm{mg} / \mathrm{kg}^{-1}\right.$ day $\left.^{-1}\right)$, respectively. Based on the FAO/WHO guidelines, the ADI for diazinon is $0.005 \mathrm{mg} / \mathrm{kg}^{-1}$ day $^{-1}$ [16]. When HRI is more than one, the food has a high health risk for humans. However, when HRI is less than one, the food will be acceptable for consumption because it will not cause an unacceptable health risk.

\section{Calculating the permissible FCR in the study area}

The permissible FCR was calculated after potential risk analysis and quantitative and qualitative assessments. The diazinon level in the body should not exceed the chronic Reference Dose (RfD). The following equation is used to calculate the maximum recommended rice consumption:
Where, $\mathrm{CR}$, $\mathrm{RfD}$, and $\mathrm{C}$ respectively represent the maximum rice consumption rate $(\mathrm{kg} / \mathrm{day})$, the reference dose $(\mathrm{mg} / \mathrm{kg} / \mathrm{day})$, and diazinon concentration in rice $(\mathrm{mg} / \mathrm{kg})$.

\section{Results and Discussion}

The mean diazinon concentration in the rice samples

Table 1 lists the results of the analysis of the rice samples when the crop was offered for sale with respect to diazinon residue. The five zones in the study area were separated based on the mean and standard deviation. The highest and lowest residual diazinon concentrations in the rice samples $(0.54$ and $0.221 \mathrm{mg} / \mathrm{kg}$ on average $)$ were recorded in the southern and eastern zones of the study area, respectively (Figure 2).

\section{Health risk evaluation}

Based on the health risk assessment calculated by the HRI (for non-cancer diseases), the consumption of rice provided in the local market does not pose a health risk for the people.

The mean body weight of the inhabitants was assumed to be $70 \mathrm{~kg}$, the average daily rice consumption per person was $0.114 \mathrm{~kg}$, and the acceptable ADI was $0.005 \mathrm{mg} /$ $\mathrm{kg}^{-1} /$ day $^{-1}$ [16]. The calculated HRI for rice consumption for the rice was offered for sale in the market was 0.13 . Moreover, the HRI value for rice consumption in each zone of the studied area was reported separately. There was no health risk posed by rice consumption in any of the five zones when the rice crop was offered for sale in the market. A comparison of the five zones revealed that the highest and lowest HRI values were respectively recorded in the central and eastern zones. The HRI values for the western, eastern, northern, southern, and central zones were $0.10,0.07,0.09,0.17$, and 0.2 , respectively. Considering that all HR values are less than one, rice consumption does not cause any considerable potential risk for human health in the study area when the rice crop is offered for sale in the local market (Figure 3).

\section{Calculating the recommended rice consumption} rate

Based on the above-mentioned formula and considering the residual diazinon concentration in the rice samples after complete removal of husks, the permissible rice consumption rate for adults and children is 0.035 and $0.017 \mathrm{~kg} /$ day, respectively. 

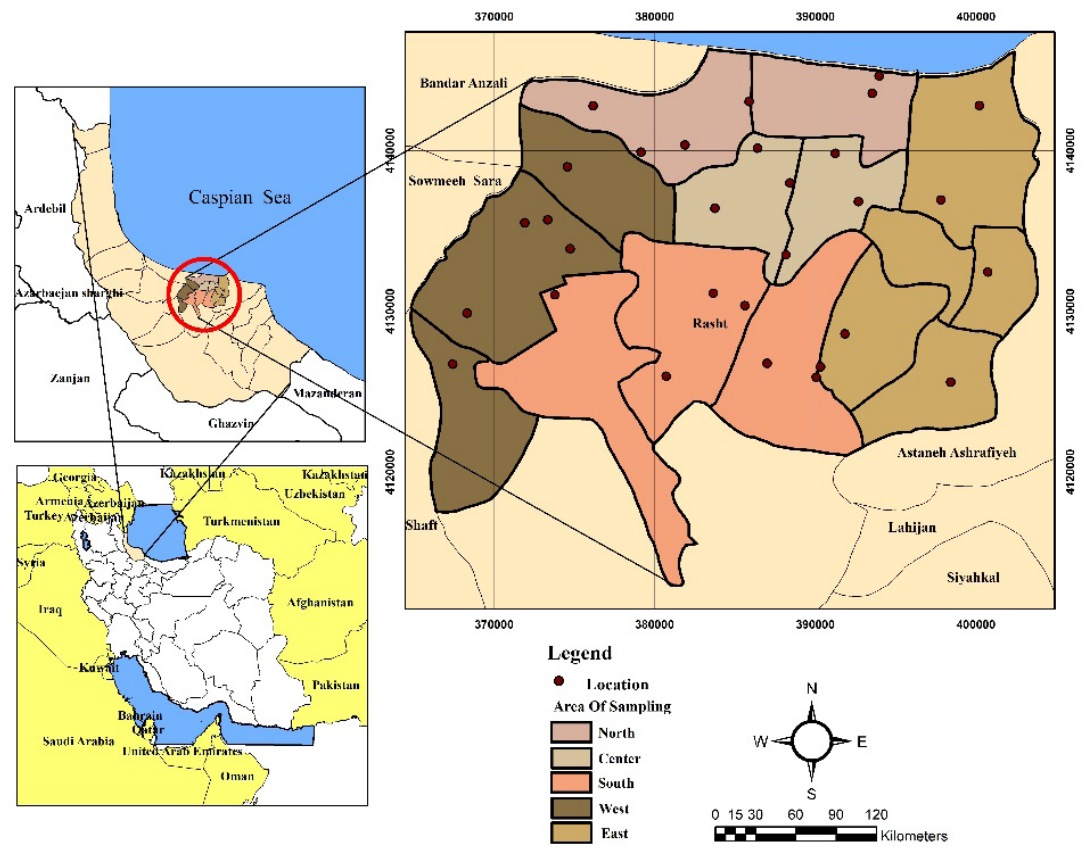

Figure 1. The studied area

\section{Pesticide residue in the rice samples}

Based on the results, there were significant differences between the five zones of the studied area with respect to the presence of diazinon in the rice samples $(\mathrm{P}<0.05)$. This confirms that the pesticide application rates and the number of applications are not the same among the rice farmers in Rasht. Accordingly, the average values are decreasing in the central, southern, western, northern, and eastern zones of the study area. The highest mean diazinon residue in the rice samples among all the stations was found at a station in the central zone, which had the highest residual diazinon concentration among the five zones in the study area. The lowest mean diazinon residue among all the stations was recorded in a station in the northern zone of the study area. Moreover, the overall mean residual diazinon concentration in the rice samples in Rasht when the rice crop was offered for sale in the market was $0.4 \mathrm{mg} / \mathrm{kg}^{-1}$, which exceeded the Maximum Residual Limit (MRL) for diazinon $\left(0.2 \mathrm{mg} / \mathrm{kg}^{-1}\right)$ set by the Institute of Standard and Industrial Research of Iran (ISIRI) in 2004. The high diazinon concentrations in the rice samples in most stations compared with the MRLs in Iran indicate that large quantities of pesticides are applied in Rasht paddy fields to obtain rice with higher qualitative and quantitative yield. The pesticide residue is still very large when the crop is offered for sale in the market, which its long-term use can cause chronic illnesses. Qu et al. [26] also pointed out the direct relationship between the quantity of the applied pesticide and its residue in plants.

There was a relationship between the time of pesticide application, the time of rice harvest, and the residual

Table 1. The residual diazinon concentrations $\left(\mathrm{mg} / \mathrm{kg}^{-1}\right)$ in the rice samples in each zone of the studied area

\begin{tabular}{cccc}
\hline Parts of the Study Area & Number of Stations & Mean \pm SD $\left(\mathbf{m g} / \mathbf{k g}^{-1}\right)$ & $0.316 \pm 0.395$ \\
\hline Western & 6 & $0.628 \pm 0.656$ \\
Central & 6 & $0.293 \pm 0.349$ \\
Northern & 6 & $0.540 \pm 0.260$ \\
Southern & 6 & 0.001 \\
Eastern & 6 & 0.003 \\
Total & 30 & $0.400 \pm 0.436$
\end{tabular}




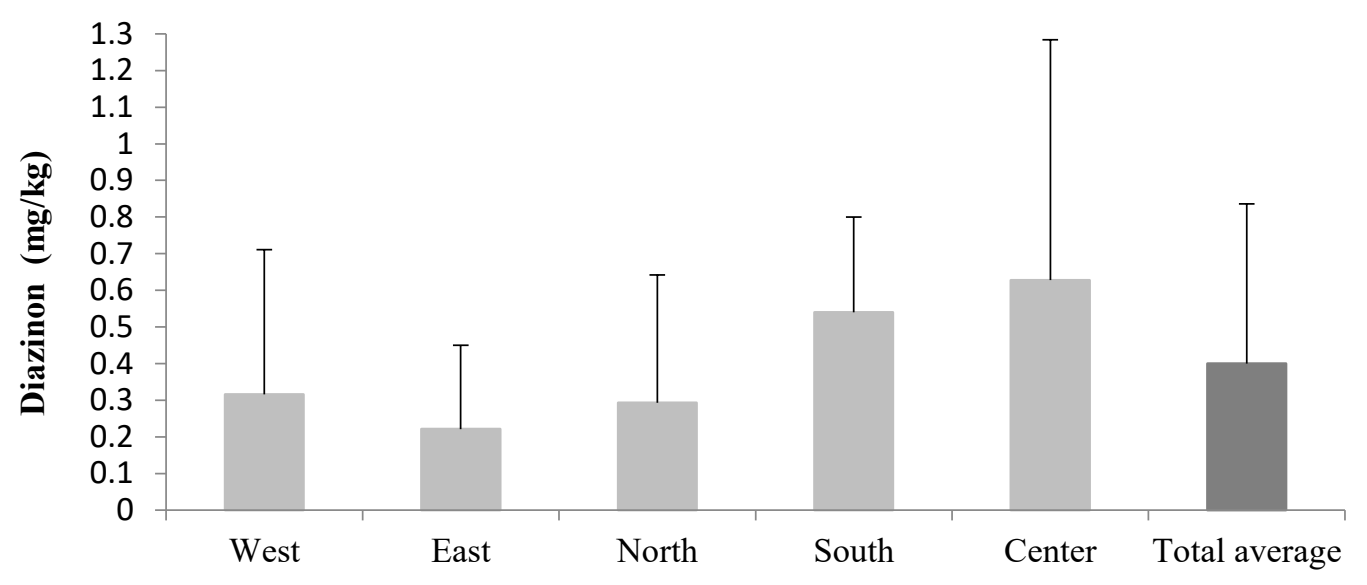

Figure 2. The average and standard deviation for the residual diazinon concentration in each zone of the studied area

concentration of pesticides. It was also recommended that studies be conducted at appropriate time intervals between rice harvest and its consumption [27, 28].

A similar study was conducted in Nepal to determine the residual concentrations of OPPs and OCPs in vegetables, including eggplants, tomatoes, and peppers. The results demonstrated the presence of pesticide residues in these three vegetables $(0.001-0.231,0.004-0.507$, and $0.013-3.465 \mathrm{mg} / \mathrm{kg}^{-1}$ in eggplants, peppers, and tomatoes, respectively) [29]. Despite the higher concentration of pesticide residue in tomatoes in this study than that in rice in the present research, their results for eggplants and peppers were almost similar to that for diazinon residue in rice in the present research. The results of a study conducted in China to detect pesticides in strawberry samples showed that the residual concentration of 26 pesticides varied from 0.01 to $2.88 \mathrm{mg} / \mathrm{kg}^{-1}$ [30].
The residual diazinon concentrations in some stations were consistent with the lowest residual concentration reported by Chua et al. [30]. The findings of a study in Vietnam on assessing the quantities of chlorinated pesticides in fish samples suggested that the residual DDT concentration in fish tissues varied from 0.182 to 0.277 $\mathrm{mg} / \mathrm{kg}^{-1}$ [31]. Although these concentrations are lower than those found in the present study, they are almost similar. Another study on drinking water in China reported that among the studied pesticides, atrazine and acetochlor were detected at 4-73.323 $\mathrm{ng} \mathrm{kg}^{-1}$ in drinking water samples [32]. These concentrations are very negligible compared with those recorded in the present study.

\section{Health risk assessment}

The HRI value for the rice crop for its regular consumers when it was offered for sale in the market in Rasht was slightly more than 0.1 . Considering rice consump-

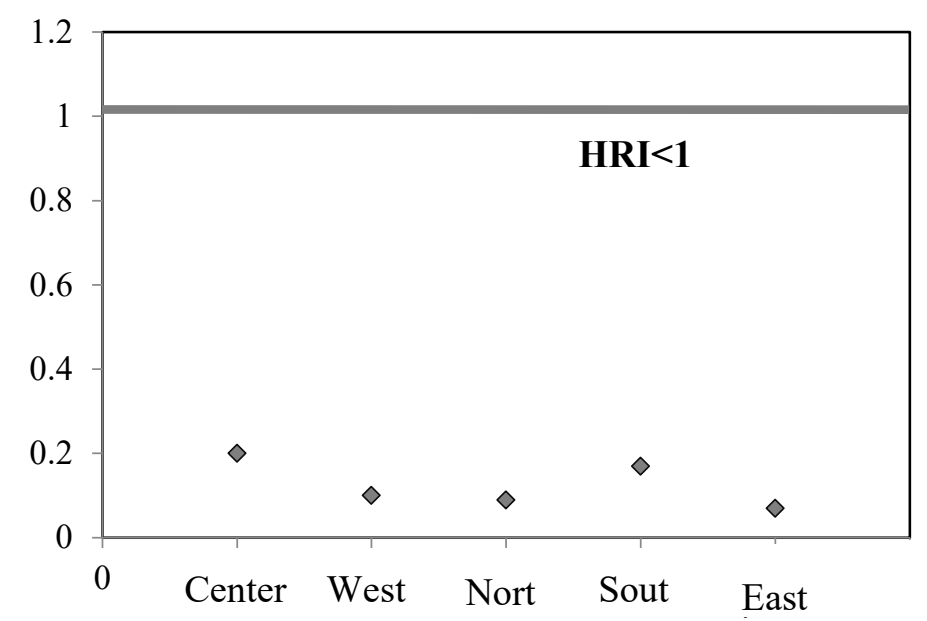

Figure 3. Health Risk Index (HRI) of diazinon residue in rice in each zone of the studied area 
tion in Rasht, this HRI value can pose a slight health risk for rice consumers. Moreover, the comparison of the HRI values for the five zones in the study area indicated that rice consumption in the southern and central zones of the studied area caused a slight health risk for rice consumers.

Evaluation of health risks caused by OPPs and carbamate in cereals, vegetables, and fruits in Nigeria revealed that the residual concentration of none of the studied pesticides exceeded the determined MRLs. The calculated HRI values for the OPPs and carbamate in none of the studied crops posed a health risk for consumers [33]. These results are consistent with those found in this study, but they reported lower health risks compared with the present study.

The health risk of 100 different pesticides in tissues of Tilapia fish was assessed. The results indicated that Tilapia did not cause health risks for the people eating this fish. In this study, the equation for the Target Hazard Quotient (THQ) was used to assess the health risk of pesticides. The THQ values for fish consumption were smaller than one, and it was unlikely that its consumption would pose a health risk for fish consumers [34]. Similar research has also shown that despite the detection of pesticides in food ingredients, their consumption will not put their regular consumers at considerable risk [35-37].

Contrary to the present research, many studies on the health risk of pesticides, in which HRI has been used in agricultural products or other food materials, have reported a high risk of developing cancers or non-cancer diseases [38, 39].

Despite the very negligible risk of the studied crop for consumers, chemical pesticides or poisons are recommended to be replaced by other methods. It is also suggested to ban the use of chemical pesticides to minimize the health risks [37]. Because diazinon residues in the rice samples exceeded $\mathrm{ADI}$ and or RfD values, the recommended rates of rice intake must be determined for the people living in the study area to minimize the undesirable effects of diazinon application in rice for humans. Considering the chronic RfD value, it was found that the recommended rate of rice intake in the study area for adults was much lower than the consumption rate.

\section{Conclusion}

Although the overall mean residual diazinon concentration in the rice samples in Rasht was $0.4 \mathrm{mg} / \mathrm{kg}^{-1}$, which exceeded the MRL for diazinon $\left(0.2 \mathrm{mg} / \mathrm{kg}^{-1}\right)$ set by the Institute of Standard and Industrial Research of Iran (ISIRI) in 2004, the HRI value was less than one. This result declared that rice consumption does not cause any considerable potential risk for human health in the study area when the rice is offered for sale in the local market.

Guilan Organization of Agriculture has reported per capita rice consumption of 32-48 kg/year (the average daily rice intake of about $0.115 \mathrm{~kg}$ ), which is three times more than the amount determined for adults. This may be the reason for the occurrence of some chronic diseases in the studied area, such as digestive diseases. However, further studies should be conducted on the relationship between pesticide residues in food materials and the occurrence of chronic diseases to confirm the health risks of pesticide residues for rice consumers in the study area. These approaches, combined with proper diet management and creating public awareness on potential health risks resulting from chronic exposure to arsenic in rice, could play a key role in risk reduction.

\section{Ethical Considerations}

\section{Compliance with ethical guidelines}

The authors hereby certify that all data collected during the research are the same as they are expressed in the manuscript, and no data from the study has been or will be published elsewhere separately.

\section{Funding}

This research did not receive any grant from funding agencies in the public, commercial, or non-profit sectors.

\section{Authors' contributions}

All authors equally contributed to preparing this article.

\section{Conflict of interest}

The authors declared no conflict of interest.

\section{Acknowledgments}

The authors wish to thank Dear Sepideh Ghanbari and Sadaf Feyzi for their kindness and support during the research. Also, we thank all people who have contributed to this research. 


\section{References}

[1] Aktar MW, Sengupta D, Chowdhury A. Impact of pesticides use in agriculture: Their benefits and hazards. Interdiscip Toxicol. 2009; 2(1):1-12. [DOI:10.2478/v10102-009-0001-7] [PMID] [PMCID]

[2] Rusinamhodzi L. Challenges in maximizing benefits from ecosystem services and transforming food systems. In: Rusinamhodzi L, editor. The Role of Ecosystem Services in Sustainable Food Systems. London: Academic Press; 2020. pp. 263-274. [DOI:10.101 http://orcid.org/0000-0003-2516-2340 6/B978-012-816436-5.00013-5]

[3] Tari K, Samarghandi MR, Jaafarzadeh Haghighi Fard N, Jorfi S, Yari AR, Panahi Fard M. Pollution status of pesticide residues in food products in Iran: A mini-review within 2008-2018. Arch Hyg Sci. 2020; 9(3):214-23. [DOI:10.29252/ArchHygSci.9.3.214]

[4] Khan MJ, Zia MS, Qasim M. Use of pesticides and their role in environmental pollution. Int J Environ Ecol Eng. 2010; 4(12):621-7. https:// publications.waset.org/2211/use-of-pesticides-and-their-role-in-environmental-pollution

[5] Xiao YM, Wang J, Wang MA, Liu JP, Yuan HZ, Qin ZH. Study on the inclusion complexes of flumorph and dimethomorph with $ß$-cyclodextrin to improve fungicide formulation. J Chem Soc Pak. 2010; 32(3):363. https://jcsp.org.pk/issueDetail. aspx?aid=378975e2-9855-40ec-8af3-f0a49d14f9d4

[6] Nougadère A, Sirot V, Cravedi JP, Vasseur P, Feidt C, Fussell RJ, et al. Dietary exposure to pesticide residues and associated health risks in infants and young children - Results of the French infant total diet study. Environ Int. 2020; 137:105529. [DOI:10.1016/j.envint.2020.105529] [PMID]

[7] Cassou E. Pesticides [Internet]. 2018 [Updated 2018 March 22]. Available from: http://documents.worldbank.org/curated/en/689281521218090562/Pesticides

[8] Hicks B. Agricultural pesticides and human health [Internet] 2012 [Updated 2012]. Available from: https://serc.carleton. edu/NAGTWorkshops/health/case_studies/pesticides.html

[9] Abdi S, Sobhanardakani S. [Determination of benomyl and diazinon residues in strawberry and its related health implications (Persian)]. Razi J Med Sci. 2019; 25(11):42-51. https:/ / www.sid.ir/fa/journal/ViewPaper.aspx?ID=468975

[10] Bhandari G, Atreya K, Scheepers PTJ, Geissen, V. Concentration and distribution of pesticide residues in soil: Non-dietary human health risk assessment. Chemosphere. 2020; 253:126594. [DOI:10.1016/j.chemosphere.2020.126594] [PMID]

[11] Mekonen S, Argaw R, Simanesew A, Houbraken M, Senaeve $\mathrm{D}$, Ambelu A, et al. Pesticide residues in drinking water and associated risk to consumers in Ethiopia. Chemosphere. 2016; 162:252-60. [DOI:10.1016/j.chemosphere.2016.07.096] [PMID]

[12] Sun J, Pan L, Zhan Y, Lu H, Tsang DCW, Liu W, et al. Contamination of phthalate esters, organochlorine pesticides and polybrominated diphenyl ethers in agricultural soils from the Yangtze River Delta of China. Sci Total Environ. 2016; 544:6706. [DOI:10.1016/j.scitotenv.2015.12.012] [PMID]

[13] Pan L, Sun J, Li Zh, Zhan Y, Xu Sh, Zhu L. Organophosphate pesticide in agricultural soils from the Yangtze River Delta of China: Concentration, distribution, and risk assessment. Environ Sci Pollut Res Int. 2018; 25(1):4-11. [DOI:10.1007/s11356016-7664-3] [PMID]
[14] Wang F, Jiang X, Bian YR, Yao FX, Gao HJ, Yu GF, et al. Organochlorine pesticides in soils under different land usage in the Taihu Lake region, China. J Environ Sci. 2007; 19(5):58490. [DOI:10.1016/S1001-0742(07)60097-7]

[15] Dar MA, Kaushik G, Chiu JFV. Pollution status and biodegradation of organophosphate pesticides in the environment. In: Singh P, Kumar A, Borthakur A, editors. Abatement of Environmental Pollutants: Trends and Strategies. Amsterdam: Elsevier; 2020. pp. 25-66. [DOI:10.1016/B978-0-12818095-2.00002-3]

[16] World Health Organization, International Programme on Chemical Safety. The WHO recommended classification of pesticides by hazard and guidelines to classification 2009 [Internet]. 2010 [Updated 2010]. Available from: https://apps. who.int/iris/handle/10665/44271

[17] Nicolopoulou-Stamati P, Maipas S, Kotampasi Ch, Stamatis P, Hens L. Chemical pesticides and human health: The urgent need for a new concept in agriculture. Front Public Health. 2016; 4:148. [DOI:10.3389/fpubh.2016.00148] [PMID] [PMCID]

[18] Kfir R, Overholt WA, Khan ZR, Polaszek A. Biology and management of economically important lepidopteran cereal stem borers in Africa. Annu Rev Entomol. 2002; 47:701-31. [DOI:10.1146/annurev.ento.47.091201.145254] [PMID]

[19] Kato-Nogachi H, Ino T, Sata N, Yamamura Sh. Isolation and identification of a potent allelopathic substance in rice root exudates. Physiol Plant. 2002; 115(3):401-5. [DOI:10.1034/ j.1399-3054.2002.1150310.x] [PMID]

[20] Khan M, Saljoqi AR, Latif A, Abdullah Kh. Evaluation of some rice varieties against rice stem borer (Tryporyza incertulas). Asian J Plant Sci. 2003; 2(6):498-500. [DOI:10.3923/ ajps.2003.498.500]

[21] Ahmad S, Zia-ul-Haq M, Imran M, Iqbal S, Iqbal J, Ahmad $\mathrm{M}$. Determination of residual contents of pesticides in rice (Oryza sativa L.) crop from different regions of Pakistan. Pak J Bot. 2008; 40(3):1253-7. https:/ / www.researchgate.net/publication/282848491

[22] Yu XY, Ying GG, Kookana RS. Reduced plant uptake of pesticides with biochar additions to soil. Chemosphere. 2009; 76(5):665-71. [DOI:10.1016/j.chemosphere.2009.04.001] [PMID]

[23] Darko G, Akoto O. Dietary intake of organophosphorus pesticide residues through vegetables from Kumasi, Ghana Food Chem Toxicol. 2008; 46(12):3703-6. [DOI:10.1016/j. fct.2008.09.049] [PMID]

[24] Akoto O, Andoh H, Darko G, Eshun K, Osei-Fosu P. Health risk assessment of pesticides residue in maize and cowpea from Ejura, Ghana. Chemosphere. 2013; 92(1):67-73. [DOI:10.1016/j.chemosphere.2013.02.057] [PMID]

[25] Wang HS, Sthiannopkao S, Du J, Chen ZJ, Kim KW, Yasin MSM, et al Daily intake and human risk assessment of organochlorine pesticides (OCPs) based on Cambodian market basket data. J Hazard Mater. 2011; 192(3):1441-9. [DOI:10.1016/j. jhazmat.2011.06.062] [PMID]

[26] Qu Ch, Qi Sh, Yang D, Huang H, Zhang J, Chen W, et al. Risk assessment and influence factors of organochlorine pesticides (OCPs) in agricultural soils of the hill region: A case study from Ningde, southeast China. J Geochem Explor. 2015; 149:43-51. [DOI:10.1016/j.gexplo.2014.11.002] 
[27] Arjmandi R, Tavakol M, Shayeghi M. Determination of organophosphorus insecticide residues in the rice paddies. Int J Environ Sci Technol. 2010; 7(1):175-82. [DOI:10.1007/ BF03326129]

[28] Shokrzadeh M, Ebadi AG, Moslemi M. Analysis of lindane residues in Sari and Neka cultivated rice of Iran. Int J Biol Biotechnol. 2015; 2(2):419-23. https://www.ijbbku.com/ assets/custom/journals/2005/2/ ANALYSIS\%20OF\%20 LINDANE \% 20RESIDUES\% 20IN \% 20SARI\% 20AND \% 20 NEKA\%20CULTIVATED\%20RICE\%20OF\%20IRAN.pdf

[29] Bhandari G, Zomer P, Atreya K, Mol HGJ, Yang X, Geissen V. Pesticide residues in Nepalese vegetables and potential health risks. Environ Res. 2019; 172:511-21. [DOI:10.1016/j.envres.2019.03.002] [PMID]

[30] Chu Y, Tong Zh, Dong X, Sun MN, Gao TC, Duan JS, et al. Simultaneous determination of 98 pesticide residues in strawberries using UPLC-MS/MS and GC-MS/MS. Microchem J. 2020; 156:104975. [DOI:10.1016/j.microc.2020.104975]

[31] Tran TAM, Malarvannan G, Hoang TL, Nguyen VH, Covaci A, Elskens M. Occurrence of organochlorine pesticides and polychlorinated biphenyls in sediment and fish in Cau Hai lagoon of Central Vietnam: Human health risk assessment. Mar Pollut Bull. 2019; 141:521-8. [DOI:10.1016/j.marpolbul.2019.03.006] [PMID]

[32] Dong W, Zhang Y, Quan X. Health risk assessment of heavy metals and pesticides: A case study in the main drinking water source in Dalian, China. Chemosphere. 2020; 242:125113. [DOI:10.1016/j.chemosphere.2019.125113] [PMID]

[33] Fatunsin OT, Oyeyiola AO, Moshood MO, Akanbi LM, Fadahunsi DE. Dietary risk assessment of organophosphate and carbamate pesticide residues in commonly eaten food crops. Sci Afr. 2020; 8:e00442. [DOI:10.1016/j.sciaf.2020.e00442]

[34] Eissa F, Ghanem Kh, Al-Sisi M. Occurrence and human health risks of pesticides and antibiotics in Nile tilapia along the Rosetta Nile branch, Egypt. Toxicol Rep. 2020; 7:1640-6. [DOI:10.1016/j.toxrep.2020.03.004] [PMID] [PMCID]

[35] Liu Y, Li Sh, Ni Zh, Qu M, Zhong D, Ye C, et al. Pesticides in persimmons, jujubes and soil from China: Residue levels, risk assessment and relationship between fruits and soils. Sci Total Environ. 2016; 542(Pt A):620-8. [DOI:10.1016/j.scitotenv.2015.10.148] [PMID]

[36] Tsygankov VY, Lukyanova ON, Boyarova MD, Gumovskiy AN, Donets MM, Lyakh VA, et al. Organochlorine pesticides in commercial Pacific salmon in the Russian Far Eastern seas: Food safety and human health risk assessment. Mar Pollut Bull. 2019; 140:503-8. [DOI:10.1016/j.marpolbul.2019.02.008] [PMID]

[37] Galani YJH, Houbraken M, Wumbei A, Djeugap JF, Fotio D, Gong YY, et al. Monitoring and dietary risk assessment of 81 pesticide residues in 11 local agricultural products from the 3 largest cities of Cameroon. Food Control. 2020; 118:107416. [DOI:10.1016/j.foodcont.2020.107416]

[38] Pardío V, Martínez D, Flores A, Romero D, Suárez V, López $\mathrm{K}$, et al. Human health risk of dietary intake of organochlorine pesticide residues in bovine meat and tissues from Veracruz, México. Food Chem. 2012; 135(3):1873-93. [DOI:10.1016/j.foodchem.2012.06.079] [PMID]

[39] Yohannes YB, Ikenaka Y, Saengtienchai A, Watanabe KP Nakayama SMM, Ishizuka M. Concentrations and human health risk assessment of organochlorine pesticides in edible fish species from a Rift Valley lake-Lake Ziway, Ethiopia. Ecotoxicol Environ Saf. 2014; 106:95-101. [DOI:10.1016/j. ecoenv.2014.04.014] [PMID] 